\section{NOTE ON THE SPECTRUM OF BRORSEN'S COMET}

$\mathrm{O}^{\mathrm{N}}$ April I and 2 I succeeded in determining the position of the green band in the spectrum of Brorsen's comet. The spectrum was so faint that the other bands could not be measured. The instrument was the $9 \frac{1}{2}$-inch equatorial of our astronomical laboratory, armed with a one-prismispectroscope. The observations were made by bringing an occulting bar, movable by a micrometer screw, into such a position that the welldefined lower (less refrangible) edge of the band in the comet spectrum should be just visible as a thin line, the rest of the band being hidden by the bar. After the pointing the flame of a Bunsen burner was brought in front of the slit, and the position of the band in the comet-spectrum was thus fixed.

It was found by four independent pointings (which all agreed within about the interval of the $b$-lines) that the central band of the spectrum of the comet coincided precisely (within the limits of perception) with the green band in the flame of the hydrocarbon.

The interest of the observation lies entirely in the fact that it seems irreconcileable with the result obtained by Mr. Huggins in 1868, who found for the same comet a spectrum having bands distinctly different in position and appearance.

According to my observation, the spectrum of Brorsen's comet no longer stands out as exceptional, but agrees with that of other comets.

The comet itself appears in my telescope as a small round nebulosity, about $40^{\prime \prime}$ in diameter, without definite nucleus, but much brighter in the centre, easily visible in the finder of 3 inches aperture, and about equal in brightness to a star of the 7 th or 8th magnitude. Before the new moon a straight narrow tail, about half a degree long, was faintly visible with a low power.

Princeton, N. Jersey, U.S.A., April 5

C. A. YOUNG

\section{NOTES}

WE learn that Congress has sanctioned the scheme for the reorganisation of the American Surveys recently commented upon in these columns. It is understood that the Geological Survey will be placed under the control of Mr. Clarence King, who has so long had charge of the Geological Exploration of the 4oth Parallel. But no details have yet reached us.

In the Paris Academy of Sciences, M. Alphonse MilneEdwards has been elected a member in place of the late $M$. Gervais, in the Section of Anatomy and Physiology; M. Abich a correspondent in the Section of Mineralogy, in place of $M$. Damour; and Mr. Lawes a correspondent in the Section of Rural Economy, in place of the late Marquis de Vibraye.

THE following are the probable arrangements for the Friday evening meetings at the Royal Institution after Easter :-April 25. Francis Galton, F.R.S. : "Generic Images." May 2. Prof. John G. McKendrick, M.D. : "The Physiological Action of Anæesthetics." May 9. Sir John Lubbock, Bart., M.P., F.R.S.: "The Habits of Ants." May 16. Prof. A. Cornu : "Étude Optique de l'Élasticité" (in French). May 23. W. H. Preece, M.R.I. : "Multiple Telegraphy, or Duplex and Quadruplex Telegraphy." May 30. Grant Allen: "The Colour-Sense in Insects ; its Development and Reaction." June 6. Prof. Dewar, F.R.S. June I3. Frederick J. Bramwell, F.R.S. : "The Thunderer Gun Explosion."

A CAtalogue of the library of the Museum of Practical Geology and Geological Survey has been lately published, compiled by Messrs. H. White and T. W. Newton, which cannot fail to be of use beyond the walls of the library of which it is a record. The arrangement is alphabetical, the author's name and important groups of works, as "Geological Surveys" and "Statistics," being printed in black thick type, secondary titles and subdivisions in italics. The pages are clear and easily read and the titles full and accurate. The price, considering that there are over 600 pages, and that only 270 copies appear to have been printed, is somewhat less than that which is generally fixed on the publications of this Department. When the Geological Survey was instituted in $\mathbf{1 8 4 3}$, its first Director, Sir Henry De la Beche, C.B., commenced the formation of a museum illustrative not only of the palæontology of the country, but of the economic application of geology to the arts and manufactures. These collections were exhibited in a small build. ing in Craig's Court, and wishing still further to foster geological study, Sir Henry presented to the Survey the whole of his scientific library. This was added to from time to time, until in 1851 these collections were removed to the Museum of Practical Geology, which was built for their reception, and to provide accommodation for the Royal School of Mines, which was then instituted, and to a certain extent associated with the Survey. Since this time, partly by the annual grant from Parliament, partly from the gifts of the various scientific societies of the world, and partly by the bequest of the late $\mathrm{i}$ Sir Roderick Murchison's library, it now numbers no less than 28,000 works, on the special subjects taught in the School of Mines, geology, mining, chemistry, biology, \&c., and it is specially rich in foreign transactions, and the works of reference useful to a mining engineer.

LORD DUFFERIN, who had accepted the presidency of the Birmingham and Midland Institute, having been compelled to relinquish that office on his appointment to the Embassy at St. Petersburg, Prof. Max Muiller was communicated with by the Council, and has signified his acceptance of the post.

THE publication of weather warnings in Switzerland will begin on May $I$ in Zurich, and on June 15 in Geneva. A telegraphic despatch, containing a description of the weather in Europe, with weather warnings, will be sent from the observatory every day, by telegraph, to any person who will pay quarterly $4 l .8 s$. and a shorter bulletin containing only a weather prognostic, will cost $\mathbf{I} l$. for three months.

Swiss papers are much alarmed by a case of infection by birds. Two brothers, merchants at Uster, in the canton of Zurich, who have a large collection of various birds and monkeys, lately received some tropical birds which were sent in a cage from Buda-Pesth. Immediately after the arrival of the birds the two brothers, the wife of one of them, and a shop-girl became sick. A third brother, who is a surgeon, understood the cause of the illness and ordered all suspicious birds to be killed, fifty or sixty in number, the cages to be destroyed, and a strong sanitary cordon around the house to be established. A tinker who had done some repairs to the cages also became sick and died in hospital, as well as an innkeeper and his wife, at whose inn the birds stayed for some days. The number of sick already has reached eight, and their state is very bad. The illness is described as a black typhus.

The third fascicule of the "Pflanzenleben der Schweiz," by M. Christ, has just appeared, and contains a very fine map which illustrates the subdivisions of the Swiss flora.

A CommitTeE has been appointed by the Paris Society of Photography to collect funds in order to erect a statue to Nicephore Niepce, who was born at Chalons-sur-Saone in 1765 . The subscriptions are to be sent in Paris to $M$. Pector, 9, rue d'Albe, or M. Koziell, 20, rue Louis-le-grand.

Mr. Clifton Ward's papers on the physical history of the English lake-district have been reprinted in a separate form from the Geological Magazine. 